\title{
INDICATOR ANALYSIS OF SOCIAL AND ECONOMIC SECURITY
}

\author{
CShvaiba D., ORCID: 0000-0001-6783-9765, Ph.D., Belarusian Trade Union \\ of Workers of Chemical, Mining and Oil Industries; Belarusian National Technical University, \\ Minsk,Belarus,shvabia@tut.by
}

\section{ИНДИКАТОРНЫЙ АНАЛИЗ СОЦИАЛЬНО-ЭКОНОМИЧЕСКОЙ БЕЗОПАСНОСТИ}

СШвайба Д. Н., ORCID: 0000-0001-6783-9765, канд. экон. наук, Белорусский профсоюз работников химической, горной и нефтяной отраслей промышленности;

Белорусский национальный технический университет, г. Минск, Беларусь, shvabia@tut.by

Abstract. Ensuring social and economic security is implemented in the system of criteria and characteristics. The criterion of social and economic security is the assessment of the state of what is happening in terms of the main processes that reflect the essence of social and economic security. Criteria-based security assessment includes assessment of: resource potential and probability of codevelopment; the value of the effectiveness of the use of resources, money and labor and its ratio to the level in developed countries, as well as the level at which the danger of internal and external properties are minimized; competitiveness of the economy; unity of territories and financial and economic space; sovereignty, independence and ability to counter external threats; social strength and criteria for the prevention and resolution of social incidents. In most cases, the system of characteristics-indicators of social and economic security should be allocated: the degree and quality of life; inflation rates; unemployment rate; financial and economic growth; lack of budget; public debt; integration into the global economy; the situation of foreign exchange reserves; the presence of the shadow economy.

Аннотащия. Обеспечивание социально-экономической безопасности реализуется в системе критериев и характеристик. Критерий социально-экономической безопасности оценка состояния происходящего с точки зрения основных процессов, отображающих суть социально-экономической безопасности. Критериальная оценка защищенности включает в себя оценки: ресурсного потенциала и вероятностей соразвития; значения результативности применения ресурсов, денежных средств и труда и его соотношения уровню в развитых государствах, а также уровню, при котором опасности внутреннего и наружного свойства сводятся к минимуму; конкурентоспособности экономики; единства территорий и финансово-экономического пространства; суверенитета, независимости и способности противодействовать наружным угрозам; общественной прочности и критериев предотвращения и разрешения общественных инцидентов. В большинстве случаев в системе характеристик - показателей социально-экономической безопасности нужно выделять: степень и качество жизни; темпы инфляции; норму безработицы; финансово-экономический рост; недостаток бюджета; госдолг; встроенность в глобальную экономику; положение золотовалютных резервов; наличие теневой экономики.

Keywords: security, social and economic security; state; society; economic entity; employee; threat; interests; economy, analysis, system, perspective. 
Ключевые слова: защищенность, социально-экономическая безопасность; государство; общество; хозяйствующий субъект; работник; угроза; интересы; экономика, анализ, система, перспектива.

Conceptually, the creation of an effective mechanism for ensuring socio-economic security of the Republic of Belarus can be based on the creation of an all-encompassing forecast, that is, a multi-level and full-scale system for tracking the dynamics of all leading socio-economic processes in the country $[1 ; 2]$.

Trivial complication is the development of clear criteria and threshold values of socioeconomic security [3, p. 82; 4, p. 309].

Ensuring social and economic security is implemented in the system of criteria and characteristics. The criterion of socio-economic security is the assessment of the state of what is happening in terms of the main processes that reflect the essence of socio-economic security [5;6].

The criteria-based assessment of security includes the assessment of: resource potential and probabilities of development; the value of the effectiveness of the use of resources, money and labor and its ratio to the level in developed countries, as well as the level at which the dangers of internal and external properties are minimized; the competitiveness of the economy; the unity of territories and financial and economic space; sovereignty, independence and the ability to counter external threats; social strength and criteria for the prevention and resolution of social incidents (https://clck.ru/CugtC; http://fom.ru/Ekonomika/12345) [8].

In most cases, in the system of characteristics-indicators of socio-economic security it is necessary to distinguish: the degree and quality of life; inflation rates; unemployment rate; financial and economic growth; budget deficit; public debt; integration into the global economy; the situation of gold and foreign exchange reserves; the presence of the shadow economy [7, p.14; 8, p. 19].

There are a number of thresholds [9, p. 65], which are accepted in international practice. Analyze them.

1. A generalized indicator of the socio-economic strength of the state is the dynamics of GDP. The 30\% threshold recorded in the United States in 1929-1933 during the depression is proposed as a limit for the fall of GDP.

2. Consumption of food products imported in other countries should not exceed $30 \%$. Beyond this threshold, there is a strategic dependence of the state on importers.

3. Investment in GDP of the state is obliged to guarantee simple reproduction.

4. The volume of exports of manufacturing sectors of the economy (in the structure of total exports) must be at least $40 \%$.

5. The unemployment rate cannot be higher than $10 \%$ of the working-age population.

6. The share of allocations to science cannot be lower than $2 \%$ of GDP.

7. The income gap between the poorest and the richest cannot be more than tenfold.

8 . At the threshold of poverty can not be more than $10 \%$ of the population.

9. The ratio of average and minimum wages cannot be lower than $30 \%$ [10, p. 32].

It is necessary to point out that for socio-economic security, not so much the characteristics themselves are important, as their threshold indicators - limit values, the violation of which hinders the normal course of development of various components of reproduction, leads to the formation of adverse, destructive consequences in the field of socio-economic security.

A number of researchers proposed to form 4 groups of thresholds:

1) macroeconomic, reflecting the key, defining features of the state interests and approved by the government level;

2) disclosing and supplementing these key features; 
3) functional and sectoral values, approved by the relevant ministries

4) socio-economic security of the territories.

The list of threshold values of indicators of social and economic security of the 1st group is given in Table.

LIMIT VALUES OF INDICATORS OF SOCIAL AND ECONOMIC SECURITY [3, p. 75]

Table.

\begin{tabular}{ll}
\hline \multicolumn{1}{c}{ Name } & \multicolumn{1}{c}{ Ed. measurements } \\
\hline & RUB \\
GDP volume & Vol. \\
Gross grain harvest & $\%$ \\
Share of fixed capital investment in GDP & $\%$ \\
The share in GDP of expenditures on equipment & $\%$ \\
Share of research expenditure in GDP & $\%$ \\
Share of innovative products in total industrial output & $\%$ \\
Share of mechanical engineering and Metalworking in industrial & $\%$ \\
production & $\%$ \\
Share of the total population of citizens with incomes below the & $\%$ \\
subsistence minimum & time \\
Income ratio 10\% of the richest to income 10\% of the poorest & $\%$ economically active average annual \\
Unemployment figure & percentage methodology \\
& $\%$ GDP \\
Level of monetization & $\%$ GDP \\
External debt & $\%$ GDP \\
Domestic debt & $\%$ of total budget expenditures \\
Amount of public debt service expenses & $\%$ GDP \\
Budget deficit & $\%$ \\
Inflation & RUB \\
Gold reserve & $\%$ \\
Ratio of external debt payments to annual exports & $\%$ \\
Amount of food imported in total food resources &
\end{tabular}

Source: elaboration of author

The income ratio of the top $10 \%$ and the bottom $10 \%$ of the population can be supplemented by two more:

Index of income concentration Lorana (formula 1):

$$
I_{\text {Л }}=\frac{\sum\left|y_{i}-x_{i}\right|}{2}
$$

where yi - the volume of income concentrated in the i-th group of the population; $x i$ - the size of the population in the i-th group.

Boundaries, which is a coefficient ranging from 0 to 1 . The closer the Lorentz coefficient is to 1 , the lower the population concentration by income.

Gini income concentration indicator (formula 2):

$$
G=1-2 \sum x_{i} C y_{i}+\sum x_{i} y_{i}
$$

where $y_{i}$ - the volume of income concentrated in the i-th group of the population; $x_{i}-$ the size of the population in the i-th group; $C \boldsymbol{y}_{i}-$ cumulative amount of income. 
The extent to which there is a coefficient ranging from 0 to 1 . The closer the Gini coefficient is to 1 , the degree of inequality (concentration of income) is lower, the closer it is to 0 , the degree of income equality is higher.

It is important to note that the highest level of protection is achieved provided that the entire list of characteristics is located within the limits of the permitted limits of the own threshold values, and the threshold values of the 1st indicator are not achieved to the detriment of others.

Among the internal dangers, the greatest threat is posed by currents in the social, scientific and technical spheres.

The public sphere plays a major role in ensuring not only socio-economic, but also state security. It is the real embodiment of the interests of the individual, society, family, as well as classes, social groups and the country. It is here that the strength and harmony of all the abundance of social relations, as well as the conflict and conflict-free relations between the individual and the state, the individual and the enterprise are tested. The greatest danger to the existence of the state and its security is represented by a sharp differentiation in the income and consumption of the population; a downward shift in the nutritional structure due to a decrease in the average consumption of more valuable food varieties and ultimately protein; an increase in poverty as a result of an absolute and conditional increase in the number of people whose income is below the subsistence level, etc.

A study of the hazards of socio-economic security shows that they cover important areas of the economy, affect the fundamental basis of human activity, directly affect the public group which means everyone is relatively resistant to an array of people interacting and the United joint interests and goals [11, p. 772].

In each state, the market economy develops as a specific functional financial and economic system (FES) with the resulting quantitative and qualitative features. Within the framework of the integral economy there are dynamic self-regulating subsystems, the work of all structural components of which is focused on maintaining macroeconomic equilibrium in the domestic market and creating suitable conditions for the exchange of information, products, technology, different forms of capital, labor, etc. Functional financial and economic systems maintain equilibrium with respect to certain specified macroeconomic characteristics.

Thus, the level of shortage of the state budget is not obliged to exceed 5\% of GDP, the amount of gold and foreign exchange reserves must be sufficient to cover the cost of import of products within 3 months, the ratio of current payments for debt service can not exceed $20 \%$ of annual income from exports, dangerous unemployment rate can not exceed 15-20\% of the working population.

Without paying attention to the relativity of the above characteristics, their maintenance at a specific level provides a balance in the domestic market and guarantees the stability and dynamism of the financial and economic recovery.

The 1st plan is now put forward tools of accounting policy and research (monitoring). This applies primarily to the information base and maintenance (we are not talking about the "raw" arrays of data accumulated in excess and haphazardly, but about the information structured for the tasks of research and management of the economy by non-administrative methods).

At the current stage, there is no sufficient legal framework for certain types and methods of state regulation, some existing regulatory instruments are at the level of by-laws, regulatory documents of the Executive power. A unified system of accounting and information support of public administration bodies is being formed very slowly and randomly.

The formulation of state interests contains a significant meaning, but it is not enough for the state to implement the function of ensuring the socio-economic security of the state. The 
characteristics that quantify the position of the economy from the standpoint of state interests are shown.

In the process of studying the dangers of socio-economic security of the state can be used a wide range of analytical indicators that characterize literally all aspects of socio-economic development of the state. At the same time, in the study of the dangers of socio-economic security and state activity on the defense of the state interests of the country in the field of economy, it is necessary to identify the "pain points", beyond which threatens the destructive processes and irreversible degradation of the economy and society.

The dangerous size of the socio-economic characteristics of security does not always indicate a situation of complete failure of the economy as a whole or of its individual areas. It is, in the first place, speak of the need of surgical intervention of the management bodies with the aim of modifying unsafe trends. As a result, the establishment of critical points of destructive development of the economy allows to limit the current freedom of assessment of the situation in the country and to find common ground between different political forces.

In this regard, from the entire array of indicators of the value of the dangers of socioeconomic security requires the allocation of those that display these dangerous "pain points". These indicators are used as thresholds of social and economic security.

Thus, the threshold values of socio-economic security are understood to be the limit values, the violation of which hinders the normal course of formation and leads to the formation of crisis trends in the economy and the standard of living of the population.

\section{References:}

1. Shvaiba, D. (2019). Dynamic regression models of forecasting indicators of social and economic security. Bulletin of Science and Practice, 5(1). 249-257.

2. Shvaiba, D. (2018). Industry of the Republic of Belarus: problems of social and economic security. Bulletin of Science and Practice, 4(9). 245-252.

3. Sengachov, V. K. (2005). Indikativnaya sistema ekonomicheskoi bezopasnosti. Ekonomicheskaya bezopasnost' Rossii, Moscow. 72-90. (in Russian).

4. Poberezhnaya, O. E., \& Dauksh I. A. (2014). Sotsial'no-ekonomicheskaya bezopasnost' gosudarstva: problema otsenki ugroz. Novaya ekonomika, (2). 306-310. (in Russian).

5. Zotin, A. (2014). Rating - a lie, but there is a hint in it. Kommersant. Money, (50). 47. (in Russian).

6. Stiglitz, J. (2015). The price of inequality. Than the stratification of society threatens our future. Moscow. Eksmo, 19. (in Russian).

7. Kadomtsev, S. V., \& Manakhov, I. V. (2015). Convergence of models of the social state on a new technological basis. Bulletin of the Saratov State Social and Economic University, (5 (59)). 12-16. (in Russian).

8. Konstantinova, L. V. (2017). Social policy as a factor in constructing inequality: a new model of paternalism. Power, (2). 16-21. (in Russian).

9. Verush, A. I. (2012). National Security of the Republic of Belarus: a course of lectures. Minsk: Amalfife, 204. (in Russian).

10. Verush, A. I. (2012). National Security: A Handbook. Minsk: Academy of Management. under the President of the Republic of Belarus, 112. (in Russian).

11. Solodovnikov, S. Yu. (2002). Sotsial'naya gruppa. Bol'shoi entsiklopedicheskii slovar': filosofiya, sotsiologiya, religiya, ezoterizm, politekonomiya. Minsk, 772. (in Russian). 


\section{Список литературь:}

1. Shvaiba D. Dynamic regression models of forecasting indicators of social and economic security // Бюллетень науки и практики. 2019. Т. 5. №1. С. 249-257.

2. Shvaiba D. Industry of the Republic of Belarus: problems of social and economic security. // Бюллетень науки и практики. 2018. Т. 4. №9. С. 245-252.

3. Сенгачов В. К. Индикативная система экономической безопасности // Экономическая безопасность России. М. 2005. С. 72-90.

4. Побережная О. Е., Даукш И. А. Социально-экономическая безопасность государства: проблема оценки угроз // Новая экономика. 2014. №2. С. 306-310.

5. Зотин А. Рейтинг - ложь, да в нем намек // Коммерсанть. Деньги. 2014. №50. С. 47.

6. Стиглиц Дж. Цена неравенства: чем расслоение общества грозит нашему будущему. М.: Эксмо, 2015. 508 с.

7. Кадомцева С. В., Монахова И. В. Конвергенция моделей социального государства на новой технологической основе // Вестн. Сарат. соц.-экон. ун-та. 2015. №5. С. 12-16.

8. Константинова Л. В. Социальная политика как фактор конструирования неравенства: новая модель патернализма // Власть. 2017. №2. С. 16-21.

9. Веруш А. И. Национальная безопасность Республики Беларусь. Минск: Амалфея, 2012. 204 c.

10. Веруш А. И. Национальная безопасность. Минск: Акад. упр. при Президенте Респ. Беларусь, 2012. 112 с.

11. Солодовников С. Ю. Социальная группа // Большой энциклопедический словарь: философия, социология, религия, эзотеризм, политэкономия. Минск, 2002. С. 772.

Работа поступила

в редакиию 26.07.2019 г.
Принята к публикациии 29.07.2019 2.

Ссылка для циитирования:

Shvaiba D. Indicator Analysis of Social and Economic Security // Бюллетень науки и практики. 2019. Т. 5. №9. С. 256-261. https://doi.org/10.33619/2414-2948/46/32

Cite as (APA):

Shvaiba, D. (2019). Indicator Analysis of Social and Economic Security. Bulletin of Science and Practice, 5(9), 256-261. https://doi.org/10.33619/2414-2948/46/32 (in Russian). 